\title{
MIDDLE PLEISTOCENE SMALL MAMMAL FAUNAS OF EUROPE: EVOLUTION, BIOSTRATIGRAPHY, CORRELATIONS
}

\begin{abstract}
The paper is concerned with the small mammal fauna evolution in Europe in the Middle Pleistocene. The information on the faunas of the end of the Early Pleistocene has been also taken into consideration. The data available made possible identifying several stages in the small mammal evolution. Not all intervals within the Middle Pleistocene are provided with sufficient information for recognizing individual stages; that is particularly true for the cold periods of the Middle Pleistocene - the Donian and the Okian glaciations (=Elsterian, =Anglian). Based on the studies of small mammal localities, the biostratigraphic scheme has been developed, the principal phylogenetic lineages of Arvicolinae were traced, and maps of the Middle Pleistocene small mammal localities have been compiled
\end{abstract}

KEY WORDS: Middle Pleistocene, small mammals, Europe, biostratigraphy, evolution, correlations

CITATION: Anastasia K. Markova, Andrey Yu. Puzachenko (2018) Middle Pleistocene small mammal faunas of Europe: Evolution, Biostratigraphy, Correlations. Geography, Environment, Sustainability, Vol.11, No 3, p. 21-38

DOI-10.24057/2071-9388-2018-11-3-21-38

\section{INTRODUCTION}

Problems of evolution of the Middle Pleistocene small mammals and the synchronization of the principal stages of their evolution with geological and climatic events have been examined in many previous publications (Agadjanian 2009; Alexandrova 1976; Chaline 1972; CuencaBescós et al. 2013; Heinrich 1990; Fejfar and Horaček 1990; Markova 1982, 2005, 2006, 2007, 2014; Markova and Kolfschoten 2012; Markova and Puzachenko 2016; Markova and Vislobokova 2016; Masini and Sala 2011; Maul 2001; Maul and Markova 2007; Maul et al. 2000, 2007; Nadachowski 1990; Rekovets 1994; Schreve 2004 a,b,c; Vislobokova and Tesakov 2013; van der Meulen 1973; van Kolfschoten 2014; von
Koenigswald and van Kolfschoten 1996 and many others). In this paper we try to analyze generally the main stages in the evolution of the European small mammal faunas referring to the period from the Jaramillo paleomagnetic event (the end of the Early Pleistocene 1.07 - $0.99 \mathrm{Ma}$, MIS 26-30) till the end of the Middle Pleistocene - the end of Saalian (=Walstonian, =Dnieper) glaciation (MIS 6). The ages of the temporal intervals were given according to oxygen isotope curve (Lisiecki and Raymo 2005). A significant number of global climatic events, glaciations and interglacials, correspond to this period. We tried to recognize the response of the small mammal faunas to the different climatic events during the Middle Pleistocene, to synchronize the faunas of Eastern Europe with those of 
Western Europe, to examine the principal evolutional changes in the different phylogenetic lineages of Arvicolinae during the Middle Pleistocene.

\section{PRINCIPAL STAGES OF THE MIDDLE PLEISTOCENE SMALL MAMMAL FAUNAS}

The end of the Early Pleistocene - the beginning of the Middle Pleistocene (MIS $31-19)$

The analysis of small mammal faunal data from Eastern and Western Europe dated to the interval from the Jaramillo paleomagnetic event to the beginning of the early Middle Pleistocene (1.06-0.7 Ma) provided evidence for several phases in the small mammal evolution recognizable within this interval. It is established that the boundary between large mammal fauna stages corresponds to those of Tamanian and Tiraspolian mammal assemblages in Eastern Europe, Early/Late Galerian in Italy, and MNQ 20/MNQ 21 zones. A more detailed picture was revealed in the evolution of small mammal faunas during the regarded interval; the phases are distinguishable by changes in the species composition, first occurrences of new species, and evolutionary changes in a several phylogenetic lineages of Arvicolidae.

On the Russian Plain most of localities are found in great geological sequences studied not only paleontologically, but also by several methods including paleomagnetic stratigraphy. Those supplementary data help to determine the stratigraphic position of mammal faunas. Many localities in the region of the Black Sea coasts include, along with mammals, shells of brackish-water mollusks differing in their evolutionary level. The mollusk assemblages permit to correlate the mammal faunas directly with the Black Sea transgressions and paleogeographic events in the Eastern Mediterranean.

A relatively large part of localities in Western Europe are related to karst caves and fissures. In such localities faunal remains of different age are often found to be mixed, and paleomagnetic analysis data are also not quite reliable. There are, however, a number of multilayered localities (Kärlich, Shöningen, Sima del Elephante, Grand Dolina, Colle Curti, Castagnone, the localities related to the different Themes River terraces, and some others) where multidisciplinary studies (including paleomagnetic analysis and absolute dating) were performed.

Every phase in the evolution of small mammals is identifiable not only by appearance of new taxa, but also by the prevalence of certain morphotypes within a taxon. The main evolutionary transformations within the phylogenetic lineages resulted from anagenesis; several "paleontological" species were identified on the basis of the dominant tooth morphotypes. In the Prolagurus - Lagurus lineage, for example, we never found a single tooth morphotype in a certain time interval; there is always a considerable variability recorded. At the level of faunas correlatable with the Jaramillo event there are some steppe lemmings with morphotypes typical of Prolagurus ternopolitanus ( $=P$. praepannonicus) against the background of prevailing tooth morphotypes characteristic of $P$. pannonicus. Faunas dated to the very end of the Matuyama reversed polarity epoch (the Karai-Dubina locality) include steppe lemmings with tooth morphotypes of $P$. pannonicus, P. posterius, L. transiens. More than $90 \%$ of the teeth feature morphotypes characteristic of $P$. pannonicus, while L. transiens is represented by a single specimen displaying the extreme variant of the morphological variability (Markova 1982). Therefore, it is easy to make a mistake in attributing a locality to another evolutionary stage (faunal assemblage) if the species list of the locality is considered formally in the absence of other datable materials. All these phenomena require a careful investigation of fossil materials. Certain difficulties in correlations between West European faunas and those in Eastern Europe arise from different levels of knowledge and different taphonomic features. 


\section{Small mammal faunas related to Jaramillo normal polarity event}

Small mammal faunas confidently correlated with the Jaramillo normal polarity event contain remains of Mimomys savini, M. pusillus, Clethrionomys sokolovi, advanced Allophaiomys, Borsodia fejervaryi, Prolagurus pannonicus, Lagurodon arankae, Eolagurus argyropuloi (Masini and Sala 2011; van der Meulen 1973; Siori and Sala 2007; Markova 2007; Maul and Markova 2007). Characteristic for the Iberian faunas is the presence of archaic representatives of the endemic Iberomys genus (I. huescarensis), voles of the Ungaromys genus and surprisingly finds of the water vole Arvicola jacobensis found together with Allophaiomys lavocati (Cuenca-Bescós 2013). It is noteworthy that no voles of Microtus (Terricola), M. (Pallasiinus),

Lasiopodomys

(Stenocranius) genera and subgenera have been recorded in faunas correlatable with the Jaramillo event. In Eastern Europe faunas of that evolutionary level had been earlier identified as Kairian (=Ostrogozhskian) small mammal faunas (Markova 1990, 2007; Shik 2014) (Fig. 1).

In Western Europe they have been correlated with West European Biharian faunas, with those of the Colle Curti stage (Colle Curti F.U.) in Italy and the "Allophaiomys lavocati" phase in Spain, etc. (Cuenca-Bescós et al. 2013; Masini and Sala 2011; Siori and Sala 2007) (Fig. 5).

The other opinion exists also that more advanced voles of Allophaiomys Microtus linage (for example, Microtus thenii) also existed during Jaramillo event (Maul et al. 2007) (Fig. 2). For our opinion it is necessary to carry out the additional studies to resolve this problem.

Small mammal faunas related to post-Jaramillo interval. but located before Brunhes - Matuama paleomagnetic boundary

The next step in the small mammal evolution is represented by faunas with the first documented representatives of
Lasiopodomys (Stenocranius) hintoni and Microtus (Terricola) sp. Mimomys savini, M. pusillus, Allophaiomys pliocaenicus nutiensis, Prolagurus pannonicus are also present in these faunas.

Those faunas were identified as the Morozovkian small mammal assemblage (Alexandrova 1976; Markova 1990) and fall within the Matuyama reversed polarity zone. It is possible that those East European faunas may be correlated with the faunas with Microtus thenii from Untermassfeld (Germany) (Maul 2001) (Fig. 1, 2, 5).

More advanced faunas are identified by the first occurrence of Microtus ex gr. oeconomus $(=M$. protooeconomus, $=M$. ratticepoides). The bulk of the fauna is formed by Prolagurus pannonicus and Eolagurus argyropuloi; remains of Mimomys savini and Allophaiomys pliocaenicus nutiensis are present in small number. According to paleomagnetic data, these faunas are correlated to the end of the Matuyama epoch. The faunas at that stage of evolution are recognized as Petropavlovkian assemblage of small mammals in Eastern Europe (Alexandrova 1976; Markova 1998) (Fig. 1, 2, 5).

The faunas marked by the first appearance of Microtus arvalinus and Prolagurus posterius (Shamin locality, Don R. basin) occur in inversely magnetized deposits and are dated to the very end of the Matuyama epoch. The presence of the above named species makes the faunas closer to the Early Tiraspolian ones. In the localities pertaining to the beginning of the Brunhes epoch the rooted voles of Mimomys genus still persist. Steppe lemmings are represented mostly by Prolagurus posterius, though remains displaying the Prolagurus pannonicus morphotype were presented long enough (up to the end of the Don glacial epoch). The genus Microtus became more diversified at that time (Agadjanian 2009; Markova 1992, 2007).

New species appeared in Western and Eastern Europe more or less simultaneously. The comparison between West European and East European faunas is considerably 


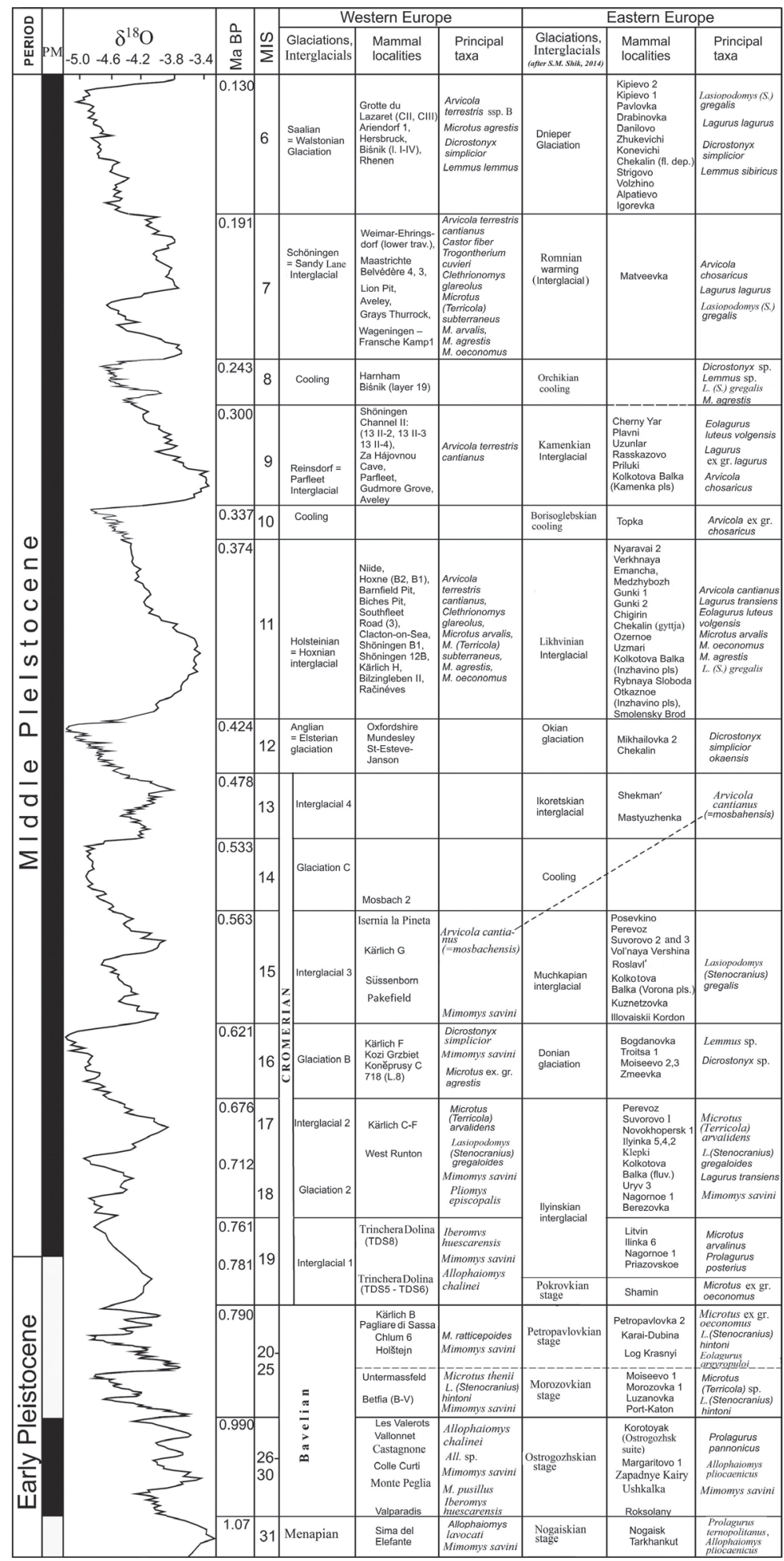

Fig.1. Biostratigraphical scheme of the Middle Pleistocene by small mammal data from Western and Eastern Europe 


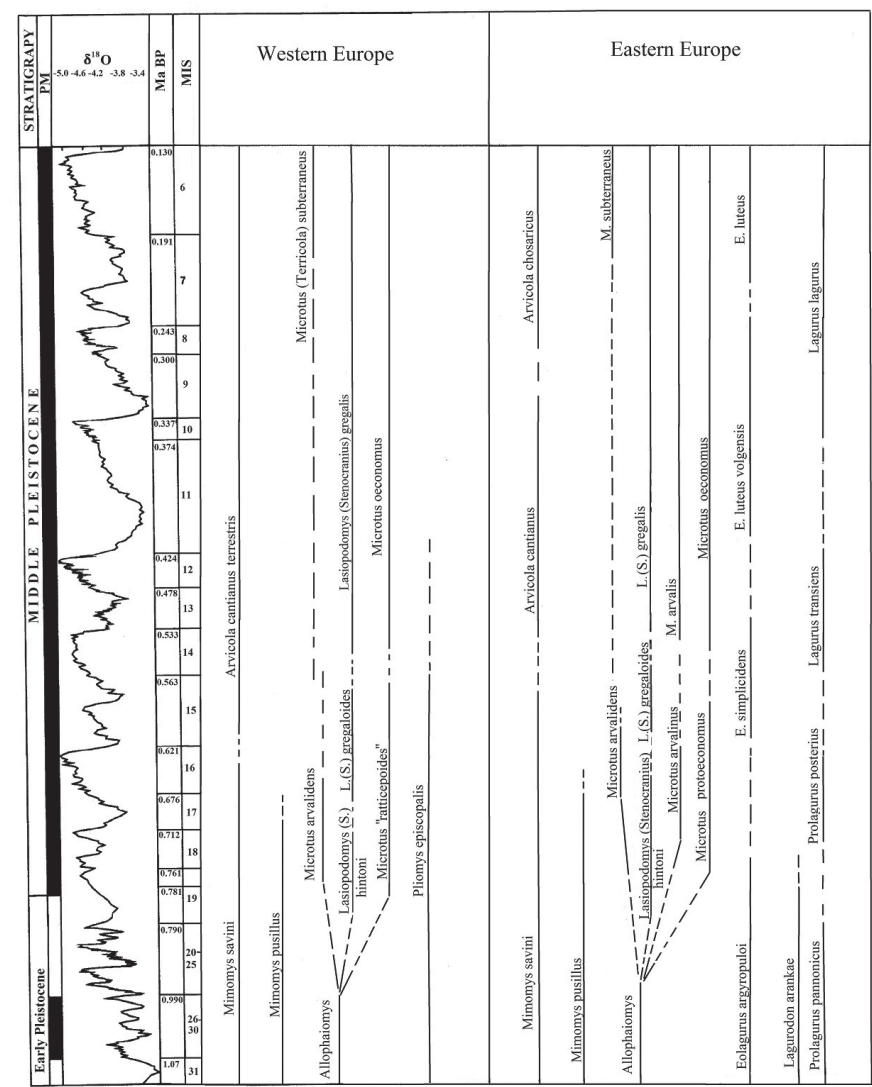

Fig. 2. Arvicolinae phylogenetic lines during the Middle Pleistocene by the materials from European localities

hindered by almost a total absence in Western Europe of steppe lemmings belonging to the Prolagurus - Lagurus lineage. Those rodents show a highly dynamic evolution through the Pleistocene and are the best diagnostic taxa for the East European faunas. The variability in the morphology of the genus Allophaiomys teeth often used by European specialists as a basis for their biostratigraphical conclusions is undoubtedly extremely important. So the indexes of M/1 are used very widely as indicative of the main trends in evolution of this taxon (van der Meulen 1973; Agusti 1992; Maul and Markova 2007, Rekovets 1994) (Fig 3).

It should be noted, however, that correlations are often performed on small collections and on insufficiently representative remains recovered from different localities. In such cases, the comparison may lead to a false conclusion. On the whole, the analysis of small mammal remains dated to EarlyMiddle Pleistocene (and of Arvicolinae in particular) is a useful tool, as it enables the evolution process to be traced in various phylogenetic lineages, and the sediments from which they originate to be dated. This palaeontological dating is particularly important, as absolute dates are practically lacking for the interval under consideration; as to the paleomagnetic method in itself, unsupported by paleontological materials, it hardly can deliver a conclusive date.

\section{First half of the Middle Pleistocene (MIS $18-12$ )}

The main intervals of the first half of the Middle Pleistocene include: Ilyinian complex interglacial (MIS 18 and 17), that apparently corresponds to the glacial A of the Cromerian complex and interglacial Cromer II; the Donian glaciation (MIS16) 


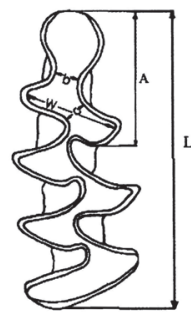

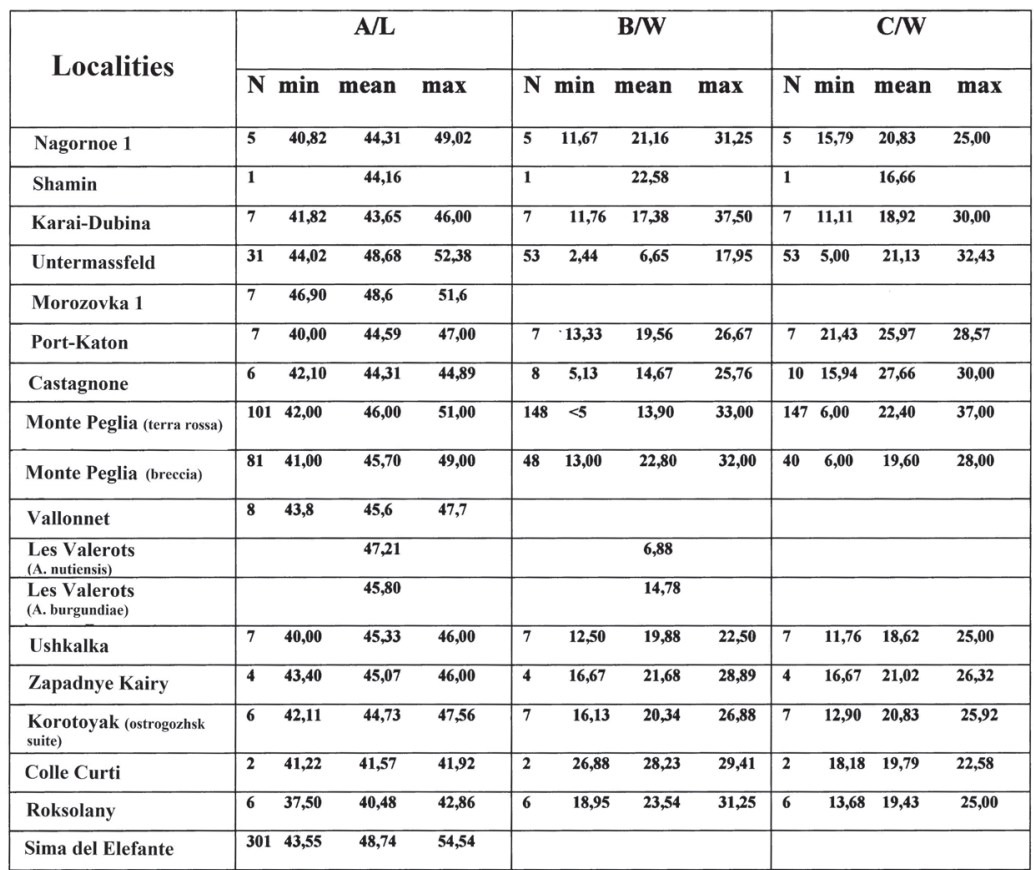

Fig. 3. Allophaiomys $\mathrm{M}_{1}$ quotient by the materials from European localities

= glaciation $\mathrm{B}$ of the Cromerian complex; the Muchkapian interglacial complex =Cromer III (MIS 15). The Muchkapian interglacial stage (by the data from Eastern Europe) includes Glazov and Konakhov warm phases and the cool interval (Podrudnyansky) separating them (MIS 15). The Navlinian cooling (MIS 14) and the later Ikoretskian warming (MIS13) follow it. The Navlinian cooling probably corresponds to the cooling (glaciation) $\mathrm{C}$ of the Cromerian complex, the Ikoretskian interglacial corresponds to Cromer IV (MIS 13), and the Okian glaciation (=Anglian glaciation $=$ Elsterian glaciation) corresponds to MIS 12 (Shik 2014). Durations of these intervals are given according to Lisiecki and Raymo (2005) (Fig 1, 2, 5). In this paper, when dealing with the materials from Eastern Europe, the authors follow the last stratigraphic scheme, proposed by Shik (2014). The West European stratigraphic subdivisions are given according to Gibbard et al. (2004).

The analysis performed on the European small mammal faunas dated to the first part of the Middle Pleistocene gives ground for distinguishing several stages in their evolutionary development during $\sim 0.76$ $0.42 \mathrm{Ma} \mathrm{BP}$

Ilyinian complicated interglacial = glacial A of the Cromerian complex and Cromer Il interglacial

The faunas of these intervals correspond to MIS 18 and MIS 17 ( 0.780 Ma - 0.676 Ma). They are characterized by the presence of rhizodont voles Mimomys pusillus, M. savini, Pliomys episcopalis, steppe 
lemmings Prolagurus pannonicus, P. posterius (dominating), Lagurus transiens, voles Lasiopodomys (Stenocranius) gregaloides, Microtus (Terricola) arvalidens, M. arvalinus, M. ex gr. oeconomus (=M. protooeconomus, $=M$. ratticepoides), and Microtus hyperboreus. Insectivores are represented by Sorex runtonensis and S. (Drepanosorex) savini. Voles of Allophaiomys genus are absent from these faunas (Agadjanian 2009; Maul and Parfitt, 2010; Markova 2007 et al) (Fig. 1, $2,5)$.

\section{Donian glaciation}

The next evolutionary stage of small mammal faunas is correlatable with the Donian glaciation, well expressed in Eastern Europe (MIS 16, 0.676 - 0.621 Ma). There are known several localities of this age. These faunas differ from the earlier ones by the presence of cold-adapted species: Dicrostonyx ex gr. simplicior and Lemmus sp. Rhizodont voles of Mimomys (M. savini) and Pliomys genera are parts of these faunas. The steppe lemmings are represented by Prolagurus posterius and Lagurus transiens; the narrow-skulled voles - by Lasiopodomys (Stenocranius) gregaloides. M. (Terricola) arvalidens, M. arvalinus, M. oeconomus (= M. ratticepoides), and $M$. hyperboreus also are present in these faunas (Agadjanian 2009, Markova 1982, 1992). According to the material from West European localities, the first documented appearance of Microtus agrestis is dated to that time (Nadachowski 1985) (Fig. 1, 2, 5).

\section{Muchkapian interglacial (=Cromer III)}

The Eastern European faunas, correlated with the Muchkapian interglacial (MIS 15, Cromer III, $\sim 0.621=\sim 0.563 \mathrm{Ma}$ ), are characterized by the presence of rhizodont voles Mimomys savini, steppe lemmings Prolagurus posterius and Lagurus transiens, voles M. (Terricola) arvalidens, M. arvalinus, and M. oeconomus. The narrow skulled voles are represented by L. (Stenocranius) gregalis, though the morphotypes of the teeth, typical for L. (S.) gregaloides, still are present in small numbers. The first appearance of $L$. (S.) gregalis distinguishes these faunas from the previous ones. In Western Europe at the beginning of this interglacial. The fauna with Mimomys savini was described (Pakefield site) (Stuart and Lister, 2001). In the second part of this interglacial. The first Arvicola was distinguished (van Kolfschoten and Turner, 1996) (Fig. 1, 2, 5). Thus, there is a significant difference in the first Arvicola appearance (FAD) in Eastern and Western Europe.

\section{Ikoretskian Interglacial (=Cromer IV)}

In the localities attributed to the Ikoretskian interglacial in Eastern Europe (Cromer IV in Western Europe, MIS 13, 0.533-0.478 Ma), the first appearance of the archaic water voles Arvicola cantianus is recorded. Rhizodont voles of Mimomys genera are not detected in these faunas (losifova et al. 2006). In West-European faunas of that age Sorex runtonensis, Drepanosorex savini, Arvicola cantianus, Microtus arvalinus, $M$. agrestis, and $M$. oeconomus have been found (Pitts and Roberts 1997 and others) (Fig. 4).

\section{Okian $(=$ Elsterian, $=$ Anglian) glaciation}

In the faunas, correlatable with the Okian (= Elsterian, = Anglian) glaciation (MIS 12; 0.478 - $\sim 0.424$ Ma), Lemmus sp., Dicrostonyx simplicior okaensis, Lagurus transiens, and $L$. (Stenocranius) gregalis have been described in Eastern Europe (Agadjanian 2009). This assemblage of small mammals undoubtedly reflects the glacial conditions of that time. Spermophilus sp., Allocricetus bursae, Lemmus lemmus, Arvicola cantianus, and $L$. (Stenocranius) gregalis have been described for this period in Western Europe (van Kolfschoten and Turner 1996). In various parts of Europe that glacial stage is represented by glacial till, fluvioglacial sediments and by loesses. The small mammal data reflect the drastic cooling and aridization during this glaciation (Fig. 1, 2, 5).

\section{The second half of the Middle Pleistocene (MIS 11 - MIS 6)}

Likhvinian (= Holsteinian, = Hoxnian) interglacial (MIS 11) 


\begin{tabular}{|c|c|c|c|c|c|c|c|c|c|c|c|}
\hline \multirow[t]{2}{*}{ Stratigraphy } & \multirow[t]{2}{*}{ MIS } & \multirow{2}{*}{$\begin{array}{l}\text { Western } \\
\text { European } \\
\text { localities }\end{array}$} & \multicolumn{4}{|c|}{ SDQ values } & \multirow{2}{*}{$\begin{array}{l}\text { Eastern } \\
\text { European } \\
\text { localities }\end{array}$} & \multicolumn{4}{|c|}{ SDQ values } \\
\hline & & & $\mathrm{N}$ & $\min$ & mean & $\max$ & & $\mathrm{N}$ & $\min$ & mean & $\max$ \\
\hline $\begin{array}{l}\text { Saalian }= \\
\text { Walstonian= } \\
\text { Dnieper } \\
\text { Glaciation }\end{array}$ & 6 & $\begin{array}{l}\text { Grotte du Lazaret, } \\
\text { CII } \\
\text { CIII }\end{array}$ & $\begin{array}{l}47 \\
8\end{array}$ & & $\begin{array}{l}107,9 \\
108,6\end{array}$ & & Igorevka & 15 & 110 & 125 & 135 \\
\hline $\begin{array}{l}\text { Schöningen= } \\
\text { Sandy Lane } \\
=\text { =Romny } \\
\text { Interglacial }\end{array}$ & 7 & $\begin{array}{l}\text { Weimar- } \\
\text { Ehringsdorf } \\
\text { (lower trav.) } \\
\text { Maastrichte } \\
\text { Belvédère 4, } \\
\text { Maastrichte } \\
\text { Belvédère } 3 \\
\text { Biśnik Cave, L.19 }\end{array}$ & $\begin{array}{l}30 \\
4 \\
66\end{array}$ & $\begin{array}{l}102 \\
86 \\
94 \\
100,65\end{array}$ & $\begin{array}{l}112 \\
102 \\
102\end{array}$ & $\begin{array}{l}126 \\
113 \\
\\
114 \\
107,1\end{array}$ & Matveevka & 1 & & 102 & \\
\hline Cooling & 8 & & & & & & & & & & \\
\hline $\begin{array}{l}\text { Reinsdorf= } \\
\text { Parfleet= } \\
=\text { Kamenka } \\
\text { Interglacial }\end{array}$ & 9 & $\begin{array}{l}\text { Shöningen- } \\
\text { Channel II: } \\
13 \text { II-2 } \\
13 \text { II-3 } \\
13 \text { II-4 } \\
\text { Aveley } \\
\text { Parfleet } \\
\text { Gudmore Grove }\end{array}$ & $\begin{array}{l}61 \\
117 \\
135 \\
2 \\
4 \\
48\end{array}$ & $\begin{array}{l}100 \\
94 \\
99 \\
\\
105\end{array}$ & $\begin{array}{l}119 \\
118 \\
115 \\
120 \\
130 \\
133,3\end{array}$ & $\begin{array}{l}150 \\
160 \\
137 \\
\\
147\end{array}$ & $\begin{array}{l}\text { Cherny Yar } \\
\text { Uzunlar } \\
\text { Plavni }\end{array}$ & $\begin{array}{l}12 \\
1 \\
13\end{array}$ & 105 & $\begin{array}{l}108 \\
110 \\
112\end{array}$ & $\begin{array}{l}125 \\
122\end{array}$ \\
\hline Cooling & 10 & & & & & & & & & & \\
\hline $\begin{array}{l}\text { Holsteinian= } \\
\text { Hoxnian= } \\
\text { Likhvin } \\
\text { Interglacial }\end{array}$ & 11 & $\begin{array}{l}\text { Niide } \\
\text { Hoxne } \\
\text { Swanscombe, } \\
\text { Bilzingleben II, } \\
\text { Barnham }\end{array}$ & $\begin{array}{l}58 \\
8 \\
4 \\
52 \\
14\end{array}$ & $\begin{array}{l}124 \\
110 \\
\\
121 \\
120\end{array}$ & $\begin{array}{l}146 \\
140 \\
140 \\
132 \\
142\end{array}$ & $\begin{array}{l}169 \\
162 \\
145 \\
170\end{array}$ & $\begin{array}{l}\text { Medzhybozh } \\
\text { L.10-11 } \\
\text { L. 14-15 } \\
\text { Gunki 1, } \\
\text { Gunki 2, } \\
\text { Chigirin, } \\
\text { Verkhnaya } \\
\text { Emancha, } \\
\text { Osernoe, } \\
\text { Rybnaya } \\
\text { Sloboda, } \\
\text { Uzmari, } \\
\text { Smolensky } \\
\text { Brod }\end{array}$ & $\begin{array}{l}25 \\
17 \\
23 \\
12 \\
48 \\
33 \\
\\
36 \\
14 \\
\\
52 \\
\\
\end{array}$ & $\begin{array}{l}91 \\
90 \\
120 \\
120,5 \\
101,7 \\
100 \\
\\
122 \\
112 \\
112\end{array}$ & $\begin{array}{l}107 \\
116 \\
125 \\
132 \\
129 \\
125 \\
\\
130 \\
125 \\
\\
130 \\
\\
\\
124 \\
\end{array}$ & $\begin{array}{l}125 \\
155 \\
169 \\
170 \\
167 \\
170 \\
\\
145 \\
160 \\
\\
140\end{array}$ \\
\hline $\begin{array}{l}\text { Elsterian= } \\
\text { Anglian }= \\
\text { Oka Glaciation }\end{array}$ & 12 & & & & & & & & & & \\
\hline
\end{tabular}

Fig. 4. Water vole Arvicola enamel thickness quotient SDQ by the materials from the Middle Pleistocene European localities

Middle Pleistocene (or the beginning of the Middle Neopleistocene in Russian stratigraphical schemes) is recognized by a noticeable warming of interglacial order - the Likhvinian (Holsteinian, Hoxnian) interglacial. This interglacial is most close to the Holocene optimum in its climatic characteristics. The deposits attributed to the Likhvinian (Holsteinian, Hoxnian) interglacial overlie those of the preceding glaciation (Elsterian in Western Europe, Anglian in Great Britain, Oka glaciation in Eastern Europe). The deposits exposed in the Hoxne stratotype in Great Britain (Layer C) have been dated by uranium series and ESR at 404+33/-42 ka BP, which fits well enough into the time limits of MIS 11 (Grün and Schwartz 2000). More than ten localities of this age were found in Eastern Europe (Markova 2006). They are distributed from the Upper Volga basin to the northern Black Sea region. Studies of the loess-paleosol series on the Russian Plain permitted to identify a horizon of fossil soil - the Inzhavino paleosol - attributable to the Likhvinian Interglacial (Velichko et al. 1992; Shik 2014).

Several very important localities were found in Western Europe. Among them, there is the famous Barnfield Pit locality in Great Britain (Swanscombe, Kent) in the south of the Thames drainage basin. The bone-bearing layers lie on those dated to the Anglian glacial epoch. The fauna was described by D. Schreve under the name 

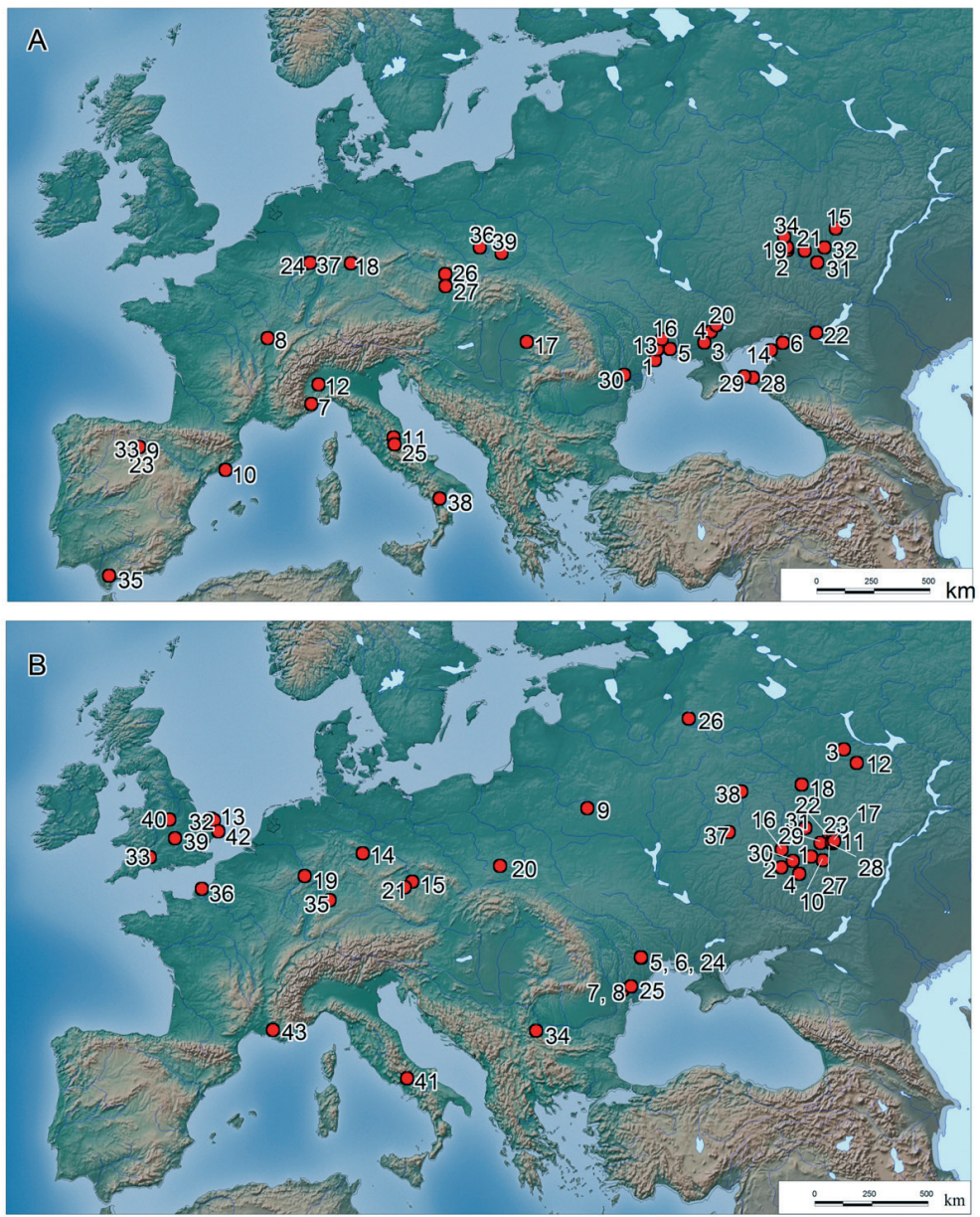

Fig. 5. A - European small mammal localities related to the end of the Early Pleistocene - to the beginning of the Middle Pleistocene (MIS 31 - MIS 19): 1 Roksolany, 2 - Korotoyak (Ostrogozhsk suite), 3 - Zapadnye Kairy, 4 - Ushkalka, 5 - Limany, 6 - Margaritovo, 7 - Vallonnet, 8 - Les Valerots, 9 - Sima del Elefante, 10

- Vallparadis, 11 - Colle Curti, 12 - Castagnone, 13 - Morozovka 1, 14 - Port-Katon, 15 - Moiseevo 1, 16 - Chirkovo, 17 - Betfia B-V,18 - Untermassfeld, 19 - Petropavlovka 2, 20 - Karai-Dubina, 21 - Log Krasny, 22 - Shamin, 23 - Trinchera Dolina (TD5-TD6), 24 - Kärlich B, 25 - Pagliare di Sassa, 26 - Chlum 6, 27 - Holštejn, 28 - Priazovskoe, 29 - Litvin, 30 - Nagornoe 1, 31 - Ilyinka 6, 32 - Novokhopersk (I.7), 33 - Trinchera

Dolina (TD8), 34 - Uryv 3, 35 - El Chaparral. 36 - Zalesiaki IA, 37 - Kärlich C, 38 Sant'Arcangelo, 39 - Kozi Grzbiet. B - European small mammal localities related to first half of the Middle Pleistocene (MIS 18 - MIS 13): 1-Ilyinka, 2 -Veret'e, 3 Zaplatino, 4 - Klepki, 5 - Kolkotova Balka (alluv.), 6 - Levada, 7 - Nagornoe I (strip. 4), 8 - Nagornoe II (strip. 2,3,5), 9 - Korchevo, 10 - Novokhopersk 1, 2, 11 - Korostylevo 1, 12 - Berezovka, 13 - West Runton, 14 - Voigtstedt, 15 - Přezletice, 16 - Bogdanovka, 17 - Moiseevo 2,3, 18 - Troitsa 1, 19 - Kärlich F, 20 - Kozi Grzbiet, 21 - Koněprusy -C718 (L. 8), 22 - Posevkino, 23 - Perevoz, 24 - Kolkotova Balka (Vorona paleosol), 25 Suvorovo 2, 3, 26 - Roslavl', 27 - Vol'naya Vershina, 28 - Kuznetsovka, 29 - Zherdevka, 30 - Mastyuzhenka, 31 - Shekhman', 32 - Ostend, 33 - Westbury (Unit 15/2 p 4), 34 - Kozarnika (L.10B), 35 - Mosbach 2, 36 -Boxgrove, 37 - Mikhailovka 2, 38 - Chekalin (Oka glacial deposits), 39 - Oxfordshire, 40 - Mundesley, 41 - Isernia la Pineta, 42 Pakefield, 43 - St-Esteve-Janson (layers F, G, H). 


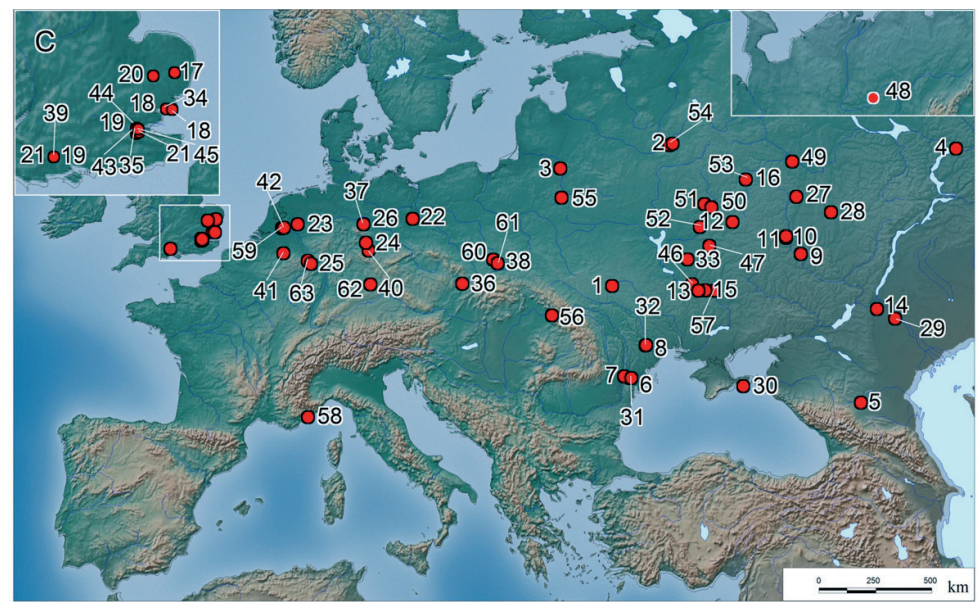

Fig. 5. C - European small mammal localities related to second half of the Middle Pleistocene (MIS 11 - MIS 6): 1 - Medzhibozh, 2 - Smolensky Brod, 3 - Nyaravai-2, 4 - Rybnaya Sloboda, 5 - Okaznoe, 6 - Ozernoe, 7 - Uzmari, 8 - Kolkotova Balka (Inzhavin. paleosol), 9 - Vladimirovka 2, 10 - Strelitsa, 11 - Verkhnaya Emancha, 12 - Mikhailovka 3, 13 - Pivikha, 14 - Raigorod, 15 - Gun'ki 1, 2, 16 - Chekalin (gittja), 17 - Hoxne (layers B2 and B1), 18 - Clacton-on-Sea, 19 - Southfleet Road (L. 3), 20 - Biches Pit, 21 - Barnfield Pit, 22 - Račinéves, 23 - Niide, 24 - Bilsingleben II, 25Kärlich H, 26 - Shöningen (13 1, 12 B), 27 - Topka, 28 - Rasskazovo, 29 - Cherny Yar, 30 - Uzunlar, 31 - Plavni, 32 - Kolkotova Balka (Kamenk.paleosol), 33 - Priluki, 34 Gudmor Grouve, 35 - Parfleet, 36 - Za Hájovnou Cave, 37 - Shöningen (L. 13 II-1, II-2, II-3, II-4), 38 - Biśnik (L. 19), 39 -Harnham, 40 - Weimar-Ehringsdorf (lower travert.), 41 - Maastrichte-Belvédère (L. 3,4), 42 - Waginingen Fransche Kamp 1, 43 - Grays Thurrock, 44 - Aveley, 45- Lion Pit, 46- Matveevka, 47 - Igorevka, 48 - Kipievo 1, 2, 49 - Alpatievo, 50 - Pavlovka, 51 - Volzhino, 52 - Strigovo, 53 - Chekalin (fluviogl. deposits), 54 - Konevichi, 55 - Zhukevichi, 56 - Danilovo, 57 - Drabinovka, 58 Grotte du Lazaret, 59 - Rhenen, 60 - Deszczowa (layers I-IV), 61 - Biśnic (L. 15-14), 62 - Hersbruk, 63 - Ariendorf 1

of Swanscombe Mammalian Zone, MAZ (Schreve 2004a). Of particular interest are remains of primitive Arvicola terrestris cantianus with SDQ index equal to $\sim 140$ $(n=4)$ (Fig. 1, 2, 4, 5). The Kärlich H locality (Germany) also attributed to this interglacial (van Kolfschoten and Turner 1996).

When studying the faunas dated to that period, much attention is given to evolutionary changes in the phyletic line of Arvicola water voles. It should be noted that the earliest stage in this genus evolution is known under different names in different European countries: Arvicola mosbachensis, or A. cantianus or A. terrestris cantianus. When describing particular faunas in the paper, we used the name of the taxon given by the author. An index designating the enamel surface ratio in the Arvicola teeth has been widely used in determination of the water vole evolutionary stage and the relative age of enclosing deposits (Markova 1975, 1981; Heinrich 1978) (Fig. 4).

The small mammal faunas of this interglacial are characterized by archaic water voles Arvicola cantianus (A. mosbachensis, = Arvicola cantianus-terrestris), Lagurus transiens, L. (Stenocranius) gregalis, M. arvalis, M. oeconomus. The rhizodon voles of Mimomys and Pliomys genus are absent from these faunas. The SDQ index of Arvicola enamel indicates the "mimomys" structure of the teeth (Fig. 4). The intensive evolutionary changes were revealed for the steppe lemming Prolagurus - Lagurus phylogenetic linage. Lagurus transiens (progressive type) was typical for the localities of Likhvinian in Eastern and Central Europe (= Holsteinian, $=$ Hoxnian) interglacial (Fig. 2). 


\section{Borisoglebskian cooling (MIS 10)}

The only locality with small mammals, Topka locality (the Don R. drainage basin), was discovered in the deposits overlying those of the Likhvinian Interglacial and in all probability belonging to the cold interval correlatable with the Borisoglebsk loess horizon (MIS 10) (Krasnenkov and Kazantseva, 1993). The locality yielded remains of Arvicola chosaricus, but no voles of the "Terricola= Pitymys" subgenus typical for Pre-Okian faunas have been found at the Topka (Fig. 1). No small mammal localities of that age are known in Western Europe (Fig. 1, 2, 5).

\section{Kamenkian $=$ Reinsdorf $=$ Parfleet Interglacial (MIS 9)}

The well pronounced warming - the Kamenka interglacial (MIS 9, 337-300 ka BP) is represented in Eastern European loesspaleosol sequence by Kamenka paleosol. This paleosol is widely spread over the Russian Plain (Velichko et al. 1992). Several localities of small mammals were described directly in this paleosol (Markova 1982) (Fig. 1, 5). The most characteristic to this interval are Lagurus ex gr. transiens - lagurus (=L. chosaricus), Arvicola chosaricus, L. (Stenocranius) gregalis, Microtus arvalis, Microtus oeconomus. The above-listed materials possibly are correlatable with the fauna from the Cherny Yar stratotypical section in the Volga drainage basin (Astrakhan Region). The Cherny Yar fauna including Arvicola chosaricus, Lagurus lagurus pleistocaenicus, Eolagurus volgensis described by Alexandrova (1976) was recovered from the same layers as the large mammal fauna described by Gromov (1948) and known since then as Khozarian mammal assemblage. The latter includes Mammuthus trogontherii chosaricus, Camelus knoblochi, Megaloceros euryceros germaniae (= M. giganteus ruffii), Bison priscus longicornis, Equus caballus chosaricus. The water vole Arvicola chosaricus is evolutionary more advanced species as compared with A. cantianus and is an indicator species of the Khozarian faunas (Fig. 2, 4). In steppe lemmings of the Lagurus genus the 'lagurus' morphotype is dominant in the faunas of the Khozarian type; more archaic 'transiens' morphotypes have been recorded in the steppe lemming remains, but their proportion is rater small (Markova 1982). The new OSL data indicate however more younger age of Khozarian fauna from the Cherny Yar stratotype locality (Zastrozhnov et al. 2017). So, till now the position of the Khozarian faunas is discussed.

The locality of Schöningen 13-II, Layers 13 II-1, I-2, I-3, II-4 includes Arvicola terrestris cantianus, Microtus (Terricola) subterraneus, M. arvalis, M. agrestis, $M$. oeconomus, L. (Stenocranius) gregalis, Apodemus sylvaticus and others. Geological data and the Arvicolinae morphological characteristics gave grounds for dating the fauna to an interglacial younger than Holsteinian - to the Reinsdorf one correlatable with MIS 9 (van Kolfschoten 2014) (Fig. 1, 2, 4, 5).

The Purfleet locality (Great Britain) is usually assigned to the second interglacial that followed the Anglian glacial stage and is correlated with MIS 9 (Schreve 2004b). The mammal fauna includes 21 taxa. Among the identified taxa are Sorex araneus, S. minutus, Arvicola terrestris cantianus, Microtus agrestis, M. arvalis, Apodemus sylvaticus and others. The water vole teeth are distinct for more advanced morphology than have Arvicola from the Barnfield Pit locality with $S D Q=130$, but more archaic than those described in water vole remains from the localities correlatable with MIS 7 (Fig. 1, 2, 4, 5). Schreve (2001 b) described this fauna as belonging to the Purfleet Mammal Assemblage-Zone MAZ Purfleet. Unfortunately the lagurides are practically absent from Western European faunas.

\section{Orchikian cooling (MIS 8)}

The Kamenka (=Purfleet, =Reinsdorf) interglacial was followed by a new cooling (MIS 8, 300-243 ka BP), which was named after the name of loess horizon distributed on the Russian Plain as the Orchikian one (Velichko et al. 1992). The faunas of this age are absent from Eastern Europe. A few localities of this age were found in Western Europe. The Harnham locality was discovered in the south of Great Britain, at the Avon and the Ebble interfluve. It was dated by OSL to approximately $250 \mathrm{ka}$ BP and attributed to the end of MIS 8 (Bates et al. 2014). The 
locality yielded some mammal bones: Apodemus sp., Clethrionomys sp. Microtus oeconomus, Microtus sp. (Fig.1, 2, 5). A unique multilayered cave site with artifacts of the Middle Palaeolithic was discovered in Poland in the south of Częstochowa Upland (Biśnic cave, layer 19) (Fig. 1, 2, 4, 5). The sequence includes several cultural layers spanning time interval from MIS 9 (?) to MIS 2 (Cyrec et al. 2010). Layer 19 correlated by Cyrec and his coauthors with MIS 8-8/7 and with the Odra glaciation yielded remains of mammal fauna, including cold-tolerant, steppe, aquatic, and forest species (Socha 2014). The fauna is dominated by cold-adapted (lemmings, narrow-skulled vole) and eurybiont species. As follows from the enamel index of water vole teeth (SDQ = 100.65-107.12) (Fig.4), the fauna may be dated to the second half of the Middle Pleistocene.

\section{Romnian, = Schöningen, = Sandy Lane interglacial}

The fauna found in the Matveevka locality on the Sula R. (the Dnieper R. drainage basin, Cherkassy Region, Ukraine, 49031' N, 32041' E) may be assigned to the end of the Romnian warming (MIS 7). The sequence includes a layer of sand and gravel with bone remains of small mammals. Upwards it is replaced with loess layer overlain in turn with the Dnieper till; still higher a loess-like loam occurs including a paleosol horizon (Krokhmal and Rekovets 2010; Rekovets, 1994). The fauna composition is as follows: Lagurus lagurus, Eolagurus sp., Arvicola chosaricus, Microtus arvalidens, M. arvalis, M. oeconomus, L. (Stenocranius) gregalis, et al. (Fig. 1, 2, 4, 5). The Lion Pit locality in the lower reaches of the Thames R. (West Thurrock, Great Britain) yielded mammal fauna including Apodemus sylvaticus, Vulpes cf. vulpes, Ursus arctos, Mammuthus trogontherii, Palaeoloxodon antiquus, Equus ferus, Stephanorhinus kirchbergensis, et al. The fauna was attributed by Schreve (2004c) to the Sandy Lane Mammal Assemblage Zone (MIS 7) (Fig. 1, 2, 5). The Aveley locality, Great Britain, was exposed in a sand quarry; the fauna includes Arvicola terrestris cantianus, Microtus agrestis or Microtus arvalis, Apodemus sylvaticus, and others. The enamel index of water voles SDQ=120 (Parfitt 1 998; Schreve 2004C) (Fig. 4).
In Central Europe several faunas were correlated with MIS 7. The small mammal fauna of the Wageningen - Fransche Kamp 1 locality (the Netherlands) includes Arvicola cantianus, Microtus arvalis/agrestis, Apodemus sylvaticus, A. maastrichensis and others and undoubtedly corresponds to a warm interval. Van Kolfschoten (2014) correlates the locality with the interglacial preceding the Saale glaciation and with MIS 7 to the Shöningen Interglacial (Fig. 1, 2, 5). A fauna closely resembling the above listed was described in the Maastrichte-Belvédère, layers 3-4. In the opinion of van Kolfschoten, it is synchronous to the previous locality and in common with it corresponds to MIS 7 (Fig.1, 2) (van Kolfschoten 2014). A rich locality of Weimar-Ehringsdorf (Lower Travertine) in Thuringia, Central Germany, contains Clethrionomys glareolus, Arvicola cantianus, Microtus oeconomus, Microtus subterarraneus, Lasiopodomys gregalis and others [Maul 2000]. Judging by the water vole enamel index (SDQ) equal to 113.5 (Heinrich, 1990), it corresponds to MIS 7 (7e/7c). The U-series dates confirm the validity of the deposits attribution to MIS 7: >350,000-200,000 yr BP (Blackwell and Schwarcz 1986). Van Kolfschoten agrees with the locality dating to the last Middle Pleistocene interglacial. MIS 7 (van Kolfschoten 2014).

\section{Dnieper, $=$ Saalian, $=$ Walstonian glaciation (MIS 6)}

More than ten Eastern European localities are correlated with the Dnieper glaciation (MIS 6). They distributed from $65^{\circ} \mathrm{N}$ to $49^{\circ} \mathrm{N}$ on the Russian Plain (Fig. 7) (Agadjanian 2009; Krokhmal and Rekovets 2010; Markova 1992; Motuzko 1985 et al.). The fauna includes coldtolerant species (Dicrostonyx cf. simplicior, Lemmus sibiricus, L. (Stenocranius) gregalis), several steppe species (Spermophilus sp., Ellobius sp., Eolagurus cf. luteus, Lagurus lagurus and others), and also sub-aquatic and meadow-plain animals (Arvicola cf. chosaricus, Microtus oeconomus, Microtus arvalis). The forest species are practically absent from the localities of this age; only Microtus agrestis and Clethrionomys glareolus occur occasionally in these faunas (Fig. 1, 2, $4,5)$. 
Several important localities were found in Western Europe (the Ariendorf 1 and the Hersbruck cave locality, Germany; the Biśnic cave locality, layers 15-14 and the Deszczowa in Poland; the Rhenen locality in the Netherlands; the Grotte du Lazaret in France) (van Kolfschoten 1990; von Koenigswald and Heinrich, 1999; Nadachowski et al. 2009; Krajcarz 2012; Chaline 1972; Socha 2014 and others). Among the small mammals recovered are Dicrostonyx cf. henseli/gulielmi, D. simplicior, Lemmus lemmus, Arvicola cantianus (=terrestris ssp.A), Clethrionomys glareolus, Microtus agrestis, Microtus arvalis, $M$. oeconomus, L. (S.) gregalis, and others. In the south of France (Grotte du Lazaret) bones of Marmota marmota, Eliomys quercinus, Microtus (=Terricola) duodecimcostatus, Pliomys lenki (=coronensis), Apodemus sylvaticus were also found (Chaline 1972). The dates obtained (by U-Th series and ESR techniques) for the cultural layer of the Grotte du Lazaret permit the site to be attributed to MIS 6 and to the last Middle Pleistocene glacial stage (Fig. 1, 2, 4, 5).

\section{CONCLUSION}

The principal trends in the small mammal evolutionary changes during the very end of the Early Pleistocene and the Middle Pleistocene have been revealed, and the East European and West European faunas were compared. An integrated analysis of theriological, geological and geochronological data available from the Middle Pleistocene localities in Europe has shown marked changes in the small mammal fauna through the period under consideration and provided information on the climate and environments at different time intervals. The changes in Arvicolinae phyletic lines made possible a correlation between the West European and East European mammal localities. They are traceable by changes in the species composition, first occurrences of new species, and morphological changes in several phylogenetic lineages.

There are some difficulties in correlation palaeogeographic picture of the past. The between West European faunas and those in Eastern Europe which arise from different levels of knowledge and different taphonomic features of the localities. On the
Russian Plain most of the localities are found in great geological sequences (mostly in the fluvial sequences overlain by the well studied loess-paleosol series). These sequences were investigated not only paleontologically, but also by several geological methods including paleomagnetic analysis. Those supplementary data help to determine the stratigraphic position of mammal faunas. Most of the localities in the region of the Black Sea coasts include, along with mammals, shells of brackish-water mollusks varying in their evolutionary level. The mollusk assemblages permit the mammal faunas to be directly correlated with the Black Sea transgressions and palaeogeographic events in the Eastern Mediterranean (Mikhailesku and Markova 1992). As is known, a significant part of localities in Western Europe are related to karst caves and fissures. In such localities faunal remains of different age are often found to be mixed, and data of palaeomagnetic analysis are also not quite reliable. There are, however, a number of multilayered localities (Kärlich, Shöningen, Sima del Elephante, Grand Dolina, Colle Curti, Castagnone, the localities from the fluvial sequences from the Thames $R$. terraces and some others) where multidisciplinary studies (including palaeomagnetic analysis and absolute dating) were performed. The correlation between the East European localities and those mentioned above are very realistic.

The relatively long time interval of the Middle Pleistocene is noted for several climatic events of global scale (glaciation - interglacial) that occurred during it. The biostratigraphic scheme of the Middle Pleistocene has been developed and maps of small mammal localities compiled (Fig. 1, 2,5).

Thus, faunas of small mammals related to the long Middle Pleistocene interval allow assessment of their taxonomy and evolutionary development. These data can also help us to divide the geological deposits by age and permit reconstruction of the results obtained may serve as an important component for compiling biostratigraphic schemes of the Middle Pleistocene and of the Pleistocene in general. 


\section{ACKNOWLEDGMENTS}

This study was supported by the RFBS grant No 13-05-00056 and by the project of Institute of Geography RAS "Mammal faunas of Northern Eurasia in the Late Pleistocene Holocene: taxonomy, diversity and evolution". We are very grateful for our reviewers for their constructive comments.

\section{REFERENCES}

Agadjanian A.K. (2009). Small mammals of the Pliocene - Pleistocene of the Russian Plain. Moscow: Nauka Press (in Russian).

Agusti J. (1992).The Allophaiomys complex in Southern Europe, Geobios, 25 (1), pp. 133-144

Alexandrova L.P. (1976). Anthropogene rodents of the European part of USSR. Moscow: Nauka Press (in Russian).

Bates M.R., Wenban-Smith F.F., Bello S.M., Bridgland D.R., Buck L.T., Collins M.J., Keen, J., Leary D.H., Parfitt S.A., Penkman K., Rhodes E., Ryssaer C. and Whittaker J.E. (2014). Late persistence of the Acheulian in southern Britain in an MIS 8 interstadial: evidence from Harnham, Wiltshire. Quaternary Science Reviews, 101, pp. 159-176.

Blackwell B. and Schwarcz H.P. (1986). U-Series analyses of the Lower Travertine at Ehringsdorf, DDR. Quaternary Research, 25 (2), pp. 215-222.

Chaline J. (1972). Les Rongeurs du Pleistocéne moyen et supérieur de la France. Paris: Cahiers de Paléontologie, CNRF.

Cuenca-Bescós G., Rofes J., López-García J.-M., Blain H.-A., Rabal-Garcés R., Sauqué V., Arsuaga J.L., Bermúdez de Castro J. M. and Carbonell, E. (2013). The small mammals of Sima del Elefante (Atapuerca, Spain) and the first entrance of Homo in Western Europe. Quaternary International. 295, pp. 28-35.

Cyrek K., Socha P., Stefaniak K., Madeyska T., Miroslaw-Grabowska J., Sudoł M. and Czyźewski Ł. (2010). Palaeolithic of Biśnic Cave (Southern Poland) within the environmental Background. Quaternary International. 220, pp. 5-30.

Gibbard P.L., Cohen K.M., Boreham S. and Moscariello A. (2004). Global chronostratigraphical correlation table for the last 2.7 million years. Subcommission on Quaternary Stratigraphy, International Commission on Stratigraphy: Cambridge.

Gromov V.I. (1948). Palaeontological and archaeological foundation of the stratigraphy of the Quaternary continental deposits in the territory of the USSR. Moscow: the USSR Academy of Sciences (in Russian).

Grün R. and Schwartz H.P. (2000). Revised open system U-series/ESR age calculations for teeth from Stratum C at the Hoxnian interglacial type locality, England. Quaternary Science Reviews, 19, pp.1151-1154.

Heinrich W.-D. (1978). Zur biometrischen Erfassung eines Evolutionstrends bei Arvicola (Rodentia, Mammalia) aus dem Pleistozän Thüringens. Berlin: Säugetierkdl. Inform., 2, pp. $3-21$.

Heinrich W.-D. (1990). Some aspects of evolution and biostratigraphy of Arvicola (Mammalia, Rodentia) in the central European Pleistocene. Prague: Int. Symp. Evol. Phyl. Biostr. Arvicolids., pp. 165-180.

Fejfar O. and Horaček I. (1990). Review of fossil arvicolids (Mammalia, Rodentia) of the Pliocene and Quaternary in Czechoslovakia. Int. Symp. Evol. Phyl. Biostr. Arvicolids. Prague: Geological Survey, pp. 125-132. 
Iosifova Yu.I., Agadjanian A.K., Pisareva V.V., and Semenov V.V. (2006). The Upper Don basin is the stratotype of the Middle Pleistocene of Russian Plain. Palynological Reconstructions: Stratigraphy, Geoecology. S.-Petersburg: Nedra Press, pp. 41-121 (in Russian) .

Krasnenkov R.V. and Kazantceva, N.E. (1993). The discovery of the early Dnieper alluvium in the Upper Don terraces, Bull. of regional commission of Central and Southern Russian Platform, 2, pp.153-161 (in Russian).

Krajcarz M.T. (2012). Small fossil wolverine Gulo from Middle Pleistocene of Poland. Acta zoologica cracoviensia, 55(1), pp. 79-87.

Krokhmal A.I. and Rekovets L.I. (2010). Pleistocene small mammal localities of Ukraine and adjacent territories. Kiev: LAT and K Press (In Russian)

Lisiecki L.E. and Raymo M.E. (2005). A Pliocene-Pleistocene stack of 57 globally distributed benthic $\delta 180$ records. Paleoceanography, 20 (1), PA1003. doi:10.1029/2004PA001071.

Markova A.K. (1975). Pleistocene rodents of Dnieper basin and its significance for the palaeogeography and stratigraphy. Aftoref. disser. na soisk. uch. stepeni kand. geogr. nauk. Moscow: Institute of Geogr. Ac. Nauk USSR Press (in Russian).

Markova A.K. (1981). Morphological changes of water voles teeth during the Pleistocene, In: A.A.Velichko and S.M. Shik, eds., The questions in Pleistocene palaeogeography of glacial and periglacial regions. Moscow: Nauka Press, pp. 91-110 (in Russian).

Markova A.K. (1982). Pleistocene rodents of the Russian Plain. Moscow: Nauka Press (in Russian).

Markova A.K. (1990). The sequence of Early Pleistocene small-mammal faunas from the South Russian Plain. Quartärpaläontologie, 8, pp. 131-151.

Markova A.K. (1992). Pleistocene microtheriofauna of Eastern Europe. In: A.A. Velichko and S.M. Shik, eds., Stratigraphy and Paleogeography of Quaternary of Eastern Europe, Moscow: Inst. of Geography RAS, pp. 50-94 (in Russian).

Markova A.K. (1998). Pleistocene rodents of the Central and Southern Russian Plain. In: J.J. Saunders, B.W. Styles and G. F. Baryshnikov, eds., Quaternary Paleozoology in the Northern Hemisphere. Illinois State Museum Scientific papers, XXVI, pp. 119-143.

Markova A.K. (2005). Eastern European rodent (Rodentia, Mammalia) faunas from the EarlyMiddle Pleistocene transition. Quaternary International. 131, pp. 71-77.

Markova A.K. (2006). Likhvin Interglacial small mammal faunas of Eastern Europe. Quaternary International. 149 (1), pp. 67-79.

Markova A.K. (2007). Pleistocene mammal faunas of Eastern Europe. Quaternary International. 160, pp. 100-111.

Markova A.K. (2014). European small mammal faunas during the end of the Early Pleistocene - the beginning of the Middle Pleistocene. Izvestia RAS, Seria geograph., 5, pp. 83-98 (In Russian)

Markova A. and van Kolfschoten T. (2012). Middle Pleistocene small mammal faunas of Eastern and Western Europe: chronology, correlation. Geography, environment, sustainability, 5(4), pp. 17-23. Available at: https://doi.org/10.24057/2071-9388-2012-5-4-17-23.

Markova A.K. and Puzachenko A.Yu. (2016). The European small mammal faunas related to the first half of the Middle Pleistocene. Quaternary International. 420, pp. 378-390. 
Markova A.K. and Vislobokova I.A. (2016). Mammal faunas in Europe at the end of the Early beginning of the Middle Pleistocene. Quaternary International. 420, pp. 363- 377.

Masini F. and Sala B. (2011). Considerations on an integrated biochronological scale of Italian Quaternary continental mammals. Italian Journal of Quaternary Sciences, 24 (2), pp. 193-198.

Maul L.C. (2000). Die Fossilfundstelle Weimar-Ehringsdorf. Eine Überisicht. Geowiss. Mitt. Thüringen, 10, pp. 167-174.

Maul L.C. (2001). Die Kleinsäugerreste (Insectivora, Lagomorpha, Rodentia) aus dem Unterpleistozän von Untermassfeld. In: R.-D. Kahlke, ed., Das Pleistozän von Untermassfeld bei Meiningen (Thüringen). Monographien des Römisch-Germanischen Zentralmuseums Mainz, 40 (3), pp. 783-887.

Maul L.C., Heinrich W.-D., Parfitt S.A. and Paunescu, A.-C. (2007). Comments on the correlation between magnetostratigraphy and evolution of Microtus (Arvicolidae, Rodentia, Mammalia) during the Early and early Middle Pleistocene. Courier Forschungsinstitut Senckenberg, 259, pp. 243-263.

Maul L. and Markova A.K. (2007). Similarity and regional differences in Quaternary arvicolid evolution in Central and Eastern Europe. Quaternary International. 160 (1), pp. 81-99.

Maul L. and Parfitt S.A. (2010). Micromammals from the 1995 Mammoth Excavation at West Runton, Norfolk, UK: Morphometric data, biostratigraphy and taxonomic reappraisal. Quaternary International. 228, pp. 91-115.

Maul L.C., Rekovets L., Heinrich W.-D., Keller T. and Storch G. (2000). Arvicola mosbachensis (Schmidtgen 1911) of Mosbach 2: a basic sample for the early evolution of the genus and a reference for further biostratigraphical studies. Senckenbergiana lethaea, 80 (1), pp. 129-147.

Mikhailesku C.D. and Markova A.K.(1992). The paleogeographical stages offauna development on the south of Moldova in Anthropogene. Kishinev: Shtiintsa Press. (In Russian).

Motuzko A.N. (1985). Anthropogene rodents of Belorussia and adjacent territories. Minsk: Nauka i Tekhnika Press, pp.173-186 (In Russian).

Nadachowski A. (1985). Biharian voles (Arvicolidae, Rodentia, Mammalia) from Kozi Grzbiet (Central Poland). Acta zool. Cracov., 29(2), pp. 13-28.

Nadachowski, A. (1990). Review of fossil Rodentia from Poland (Mammalia). Senckenbergiana Biologica, 70(4/6), pp. 229-250.

Nadachowski A., Žarski M., Urbanowski M., Wojtal P., Miekina B., Lipecki G., Ochman K., Krawczyk M., Jakubowski G. and Tomek T. (2009). Late Pleistocene Environment of the Czêstochowa Upland (Poland) reconstructed on the basis of faunistic evidence from archaeological cave sites. Kraków: Institute of Systematic and Evolution of Animals, Polish Academy of Sciences.

Parfitt S. (1998). The interglacial mammalian fauna from Barnham. In: N. Ashton, S.G. Lewis and S. Parfitt, eds., Excavations at the Lower Palaeolithic Site at East Farm, Barnham: 1989-94. London: British Museum Occasional Paper, 125, pp. 111-147.

Pitts M. and Roberts M. (1997). Fairweather Eden: Life in Britain half a million years ago as revealed by the excavations at Boxgrove. London: http://en.wikipedia.org/wiki/Random_ House ISBN 9780712676861.

Rekovets L.I. (1994). Anthropogene small mammals from the southern part of Eastern Europe. Kiev: Naukova Dumka Press (In Russian).

Schreve D.C. (2004a). The mammalian fauna of Barnfield Pit, Swanscombe, Kent. The Quaternary mammals of Southern and Eastern England. Field Guide. EuroMam UK, pp. 29-48. 
Schreve D.C. (2004b). Late Middle Pleistocene (MIS 9) river Thames terrace deposits at Purfleet, Essex. The Quaternary mammals of Southern \& Eastern England. Field Guide. EuroMam UK, pp. $49-67$.

Schreve D.C. (2004c). The mammalian fauna of the penultimate (MIS 7) interglacial in the lower Themes valley. The Quaternary mammals of Southern and Eastern England. Field Guide. EuroMam UK, pp. 69 - 79.

Shik S.M. (2014). Neopleistocene of central European Russia (the new ideas on stratigraphy and palaeogeography). Stratigraphy. Geol. Correlation, 22 (2), pp. 108-120 (In Russian).

Siori M.S. and Sala B. (2007). The mammal fauna from the late Early Biharian site of Castagnone (Northern Monferrato, Piedmant, NW Italy). Geobios, 40, pp. 207-217.

Socha P. (2014). Rodent palaeofaunas from Biśik Cave (Krakow-Częstochowa Upland, Poland): palaeoecological, palaeoclimatic and biostrtigraphic reconstruction. Quaternary International. 326-327, pp. 64-81.

Stuart A.J. and Lister A.M. (2001). The mammalian faunas of Pakefield/Kessingland and Corton, Suffolk, UK: evidence for a new temperate episode in the British early Middle Pleistocene. Quaternary Science Reviews, 20, pp. 1677-1692.

Van Kolfschoten T. (2014). The Palaeolithic locality Schöningen (Germany): A review of the mammalian record. Quaternary International. 326-327, pp. 469-480.

Van Kolfschoten T. (1990). Review of the Pleistocene arvicolid faunas from the Netherlands. Prague: Int. Symp. Evol. Phyl. Biostr. Arvicolids, pp. 255-274.

Van Kolfschoten T. and Turner E. (1996). Early Middle Pleistocene Faunas from Kärlich and Miesenheim I and their biostratigraphic implication. In: Turner C., ed., The early Middle Pleistocene in Europe. Balkema, Rotterdam, pp. 227-253.

Van der Meulen A.J. (1973). Middle Pleistocene smaller mammals from the Monte Peglia (Oriento, Italy) with special reference to the phylogeny of Microtus (Arvicolidae, Rodentia). Quaternaria, 17, pp. 1-144.

Velichko A.A., Markova A.K., Morozova T.D., Nechaev V.P., Svetlitckaya T.V., Tcatckin A.I. and Chichagova O.A. (1992). The geochronology of loess-soil formation S-W of the Russian Plain by new data. Geochronology of the Quaternary. Moscow: Nauka Press, pp. 28-33 (In Russian).

Vislobokova I. and Tesakov A. (2013). Early and Middle Pleistocene of Northern Eurasia. In: Elias S.A., ed., The Encyclopedia of Quaternary Science, vol. 4. Amsterdam: Elsevier, pp. 605-614.

Von Koenigswald W. and Heinrich, W.-D. (1999). Mittelpleistozäne Säugetierfaunen aus Mitteleuropa - der Versuch einer biostratigraphischen Zuordnung. Darmstädter Beiträge zur Naturgeschichte, 9, pp. 53-112.

Von Koenigswald W. and van Kolfschoten, T. (1996). The Mimomys - Arvicola boundary and the enamel thickness quotient (SDQ) of Arvicola as stratigraphic markers in the Middle Pleistocene. In. Turner C., ed., The early Middle Pleistocene in Europe. Balkema, Rotterdam, pp. 211-226.

Zastrozhnov A., Danukalova G. and Murray A. (2017). New data on the age of the Neopleistocene deposits of the lower Volga sites according to the OSL method results. Fundamental problems of Quaternary: the results of investigation and the main directions in the future. Moscow: GEOS, pp. 139-140. 


\section{AUTHORS}

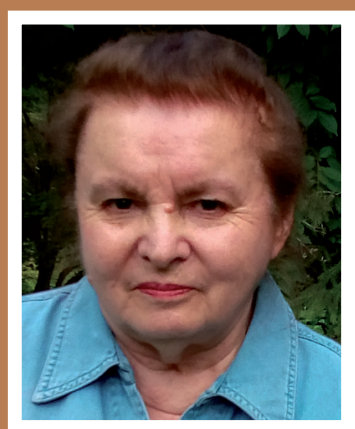

Anastasia K. Markova is specialist of Quaternary palaeontology and historical biogeography and works in the Laboratory of Biogeography of the Institute of Geography RAS. She is the Doctor of Geographical Sciences. Her main fields of interests focused on the evolutional peculiarities of Pleistocene small mammals, their taxonomy, geographical distribution in the past and palaeoecology. She leaded the intra-institutional scientific collective, which study the species composition, biodiversity and distribution of Late Pleistocene and Holocene mammals of Northern Eurasia. She is the member of Russian Quaternary Commission and the member of editorial board of the journal "Stratigraphy. Geological correlation". A.K. Markova published more than 250 scientific papers including 4 monographs, chapters in 8 collective monographs and chapters in 4 palaeogeographical atlases.

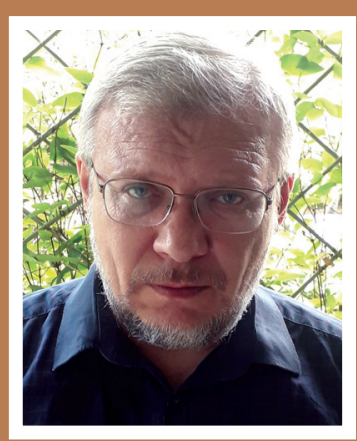

Andrey Yu. Puzachenko is a specialist in vertebrate zoology and historical biogeography. He works in the Laboratory of Biogeography of the Institute of Geography RAS. He is the Doctor of biological Sciences. His main fields of interests focus on morphological diversity of recent and extinct mammal species and the evolution of the Pleistocene mammalian faunas in the Holarctic during the Middle and the Late Pleistocene. A. Yu. Puzachenko published 191 scientific articles in Russian and international journals, and chapters in 13 collective monographs. 